\title{
Evaluating the Practices of Running the MA in Teaching English as a Foreign Language (TEFL) Program in Government Public Universities of South Nation, Nationalities and Peoples Regional State (SNNPRS) of Ethiopia: The Case of Three Universities in the Regional State
}

\author{
Yirgu Asres Dory \\ College of Social Sciences and Humanities, Hawassa University, Hawassa, Ethiopia \\ Email: yir_dor@yahoo.com
}

How to cite this paper: Dory, Y. A. (2019). Evaluating the Practices of Running the MA in Teaching English as a Foreign Language (TEFL) Program in Government Public Universities of South Nation, Nationalities and Peoples Regional State (SNNPRS) of Ethiopia: The Case of Three Universities in the Regional State. Creative Education, 10, 2311-2333.

https://doi.org/10.4236/ce.2019.1011165

Received: August 7, 2019

Accepted: November 2, 2019

Published: November 5, 2019

Copyright $\odot 2019$ by author(s) and Scientific Research Publishing Inc. This work is licensed under the Creative Commons Attribution International License (CC BY 4.0).

http://creativecommons.org/licenses/by/4.0/

\section{(c) (i) Open Access}

\begin{abstract}
The objective of this study was to evaluate the practices of running the MA in Teaching English as a Foreign Language (TEFL) program in government public universities of South Nations, Nationalities and Peoples Regional State (SNNPRS) of Ethiopia. To that end, three universities in the regional state were purposely selected as research sites. Questionnaires, interviews and resource center and thesis defense sessions' observations were used for gathering relevant data. Experienced TEFL instructors, MA TEFL prospective graduates, English Language and Literature Department heads and TEFL postgraduate coordinators were respondents in the study. Then the data gathered were analyzed using both quantitative and qualitative methods. The findings of the analysis indicate that the departments in the universities face several constraints in the practices of running the program and graduating highly qualified professionals in the field. According to the findings of the study, lack of basic knowledge and skills in the students to pursue the program effectively and lack of effort to develop their knowledge and skills in the area are the major constraints. In addition, lack of facilities and materials, lack of emphasis to quality rather than quantity, lack of commitment in some instructors and shortage of instructors in some universities are constraints that hamper the practices of effectively running the program and producing MA TEFL professionals at the aspired standard.
\end{abstract}

\section{Keywords}

Evaluating, Practices, MA, TEFL, Program 


\section{Introduction}

\section{What is (Educational Program) Evaluation?}

Jarvis and Adams (1979) point out that the term evaluation is hazy and complex to define. These scholars say that this term is in one hand used to evaluate our daily activities and choices to make judgments about these activities and choices. These scholars on the other hand indicated the complexity of defining the term in the professional context and quoted what Tyler et al. (1967) note regarding the need to consider the complex phenomenon in defining it in the context of educational programs in particular: their purposes, content, environment, methods and changes to be brought about

Albeit the imprecision and complexity of defining the word evaluation, several scholars delineate evaluation in general and educational program evaluation in particular. Keating (2011) cited in Stavropoulou and Stroubouki (2014) defines evaluation as a process of gathering data about an entity to determine its worth and to make value judgment about it. Similarly Oerman and Gaberson (2009) cited in Stavropoulou and Stroubouki (2014) describe evaluation as a "process of making judgment about learning, achievement, performance, employees' competence and educational programs based on" collected data. Stufflebeam (2003) cited in Wang (2009), likewise, added that evaluation as a systematic investigation of the value of a grogram or as a process of delineating, obtaining, reporting and applying descriptive and judgmental information about a program's merit, worth, probity and significance.

Sanders \& Sullins (2006) cited in Wang (2009) depicts that educational program evaluation deals with collecting and documenting information about a particular educational program to enable valid decision making. Frye \& Hemmer (2012) also describes program evaluation as systematic collection and analysis of information related to the design and implementation and outcomes of a program for the purpose of monitoring and improving the quality of the program. McNamara (2000) cited in Wang (2009) in the same vein defines educational program evaluation as a vigilant and systematic process of gathering information about a program or aspects of a program in order to make necessary decision about it. Brawn (1995) cited in Dollar et al. (2014) furthermore describes program evaluation as the systematic collection and analysis of all relevant information necessary to promote the improvement of the program and to evaluate its effectiveness within the context of the particular institution involved.

From the above discussions, we can understand that educational program evaluation involves a purposeful and systematic process of gathering relevant information, analyzing the information gathered, writing up reports and disseminating the reports to enable making decisive, intelligent, neutral and valid conclusion regarding attainment of objectives and advancement in achieving objectives, and improvement in program implementation. We can also understand that evaluation can be about ongoing educational program to provide 
feedback for its improvement or about a completed educational program to make decision on the success or failure in attaining the intended goals and objectives. The purpose of conducting this evaluation research was in line with the first sort as it is about the ongoing MA TEFL program so as to provide feedback for its improvement.

\section{Approaches and Models of Evaluation}

There have been various approaches/models of evaluation. Earlier approaches/models to evaluation focused on outcome and on the quality of the result of the program's functioning (Brinkerhoff, 1983). Recently, however attempts have been made to broaden the scope of evaluation variables in various educational models (Brinkerhoff, 1983; Stavropoulou \& Stroubouki, 2014).

Frye \& Hemmer (2012) discuss four familiar approaches/models: 1) experimental/quasi-experimental approach, 2) Kirkpatrick's four levels approach, 3) the Logic Model and 4) the Context/Input/Process/Product (CIPP) model. The experimental/quasi-experimental models were some of the earliest models for evaluating educational programs. This model explicitly isolates individual program elements for study and found less useful in the complex environment of educational program. Kirkpatrick's four-level evaluation mode has been used for evaluating learner outcomes. It has been criticized for failing to consider intervening variables and for assuming causality between the educational program and its outcomes. The Logic Model focuses on the changing process and the system within which the educational improvement is rooted. The major pitfall of this model lies on its inherent linearity and disregard for unexpected outcomes. CIPP Model, however, focuses on program improvement without being restrained by the assumption of linear relationships that inhibits the Logic Model.

Of these four evaluation approaches/models, the CIPP model is found to be a useful approach for evaluating educational program as it considers complexity and dynamism of the educational process and nonlinear relationships among its elements. This approach comprises four complementary sets of evaluation components: context, inputs, process, and products that allow evaluators to consider important program dimensions. Taken together, these components accommodate the ever-changing nature of most educational programs and address all its phases: planning, implementation and final assessment.

The context component is employed to identify program goals and priorities by assessing needs, problems, assets, and opportunities relevant to the program. The input element prepares evaluators to explain clearly why and how a given approach was selected and what alternatives were considered. The process component is utilized to assess implementation of a program and to interpret its outcomes. The product evaluation study focuses on program outcomes, including positive and negative, intended and unintended and short-term and long-term outcomes. CIPP model in general allows examining changes in program and considering the complexity of the educational process. Hence, it was considered suitable to be used in the current evaluation research. 


\section{Statement of the Problem}

In this age of globalization, English language is serving as a medium of effective communication between people of different languages (Mede \& Uygun, 2014). In Ethiopian context, English language also plays a pivotal role in fulfilling educational, administrative and business demands (Eshetie, 2010). Of these roles, the instructional role is key in assuring quality of education. This necessitates offering quality English language education. Some studies; however, show that the quality of English language education has been challenged by various factors; shortage of well qualified academic staff has been among the major challenges (Anto et al., 2012).

In considering the significant roles that the English language plays generally in the world and specifically in Ethiopia, an attempt has been made to give some emphasis for teaching English language in the education and training policy and attempts have been made to improve its quality though there have been different challenges. To this effect, among other things, great investment has been made on improving English language teachers professional skills at colleges and universities (Institute of International Education, 2012). In connection with this, the MA TEFL programs are launched in many of the public universities in Ethiopia.

The three government public universities in SNNPRS (Hawassa, Dilla, and Wolayta Sodo) which were selected for the purpose of this study launched the program from 2011 to 2013 with the goal of satisfying the demand of English language professionals in the area. The program takes two years for regular division, three years foe weekend division and four years for summer division (Dilla University, Hawassa University, \& Wolayta Sodo University, 2011-2013).

Launching educational program; however, does not guarantee the production of professionals at the anticipated standard. The attainment of the aspired goals and objectives in producing these professional requires input, process and monitoring. The necessary inputs must be available and accessible and there must be committed stakeholders, in particular, instructors, learners and administrators to run and monitor the program successfully and to achieve the planned goals and objectives.

As mentioned earlier, the universities have set similar goals and objectives in their curricula based on the demand of TEFL professionals in the country. But there are some indications that the MA in TEFL program is not running effectively to attain these goals and objectives. Several factors may be attributed for the failure including lack of necessary inputs, committed stakeholders and follow up. The researcher of this study has heard from some instructors and students that the courses offered are not adequate to achieve the set goals and objectives and there is scarcity of necessary inputs. Moreover, there seems to be lack of adequate initiation and commitment from the major stakeholders.

At international level, some studies were carried out on evaluating MA-TEFL programs. For example, Soontornwipost (2008) evaluated the impact of Masters 
TEFL program on the graduate of Language Institute in Thailand; Aliakbari \& Ghoreyshi (2013) evaluated the Masters of Arts Program in Teaching English as a Foreign Language in Iran; Dollar et al. (2014) evaluated the MA-TEFL program at Foundation University in Turkey; Kader (2016) evaluated the effectiveness of MA in ELT/TESOL curriculum in Abrac Institute, and Abbasian \& Teheri (2016) evaluated TEFL MA Program in Terms of Compatibility with Common Standards. In Ethiopian, however, as far as the current researcher's reading is concerned, no study conducted to check whether the MA-TEFL program is running successfully or not. Thus, the researcher thought that it was significant to conduct an evaluation study on the program to provide reliable and valid information on the practices of running the program. This inspired the current researcher to carry out the research hoping that it may contribute a lot in assuring quality of English language education at all levels in general and at MA level in particular. In doing so, the researcher found the CIPP model appropriate to evaluate mainly the input and process components of the MA in TEFL program.

\section{Objectives of the Study}

The general objective of this research was to evaluate the practices in running MATEFL Program in three government universities in SNNRS.

The specific objectives of this study were to assess:

- if students possess basic knowledge and skills to pursue the program and make adequate effort to become highly qualified professionals in the area;

- if adequate and quality materials, facilities and well qualified instructors are available and accessible;

- if admission of students is executed carefully by involving all concerned parties; and

- whether the courses that the MA TEFL students take are adequate to develop their knowledge and skills in the area.

\section{Methods and Materials}

\subsection{Research Setting}

The three universities (Hawassa, Dilla and Wolayta Sodo) in SNNPRS were selected as research setting. These universities were selected because of three reasons. First, they use non-modular curricula for the program, second, they have similar goals and objective and third Hawassa University is the researcher's work place and the remaining two are located relatively close to Hawassa University.

\subsection{Participants of the Study}

There are 27 TEFL instructors in the three universities (18 in Hawassa, 5 in Dilla and 4 in Wolayta Sodo). Of these 22 are assistant professors and the remaining 5 are associate professors. From these, 21 instructors who have experience in teaching MATEFL courses were chosen using both quota and purposive sampling methods to fill in questionnaire: 14, 4 \& 3 instructors from Hawassa, Dilla 
and Wolayta Sodo universities respectively. On the other hand, for interview 8 instructors, i.e. 5, 2, \& 1 from Hawassa, Dilla and Wolayta Sodo Universities respectively were selected. From the 100 MA TEFL students who completed their course work and started conducting their theses in the three universities, 3o were chosen to fill in the questionnaire using simple random sampling technique. All former and current English Language and Literature Department heads and post graduate coordinators of the program in the three universities, totally 8,4 department heads and 4 coordinators, were also respondents for the interview.

\subsection{Data Collection Instruments}

In order to collect relevant data for the study, questionnaires, interviews, thesis defense sessions and resource centers observations were used.

\subsubsection{Questionnaires}

Questionnaires contained both open-ended and close-ended items were prepared with the purpose of obtaining information concerning the students' readiness to pursue the program and the effort they make, the selection of students for the program, availability and accessibility of quality facilities and materials and adequacy of instructors, courses and support rendered to the students.

\subsubsection{Interviews}

Semi-structured interviews were prepared for instructors, department heads and program coordinators to supplement information not obtained from the questionnaires and to cross-check the responses of the questionnaires.

\subsubsection{Resource Centers and Defense Sessions Observations}

The researcher observed the three universities' resource centers and consulted some librarians and directors to investigate if there were adequate and up-to-date library, internet and other services. Then, he assessed if there were adequate and up-to-date reference materials and e-book services in the libraries, if the English Language Improvement Centers (ELICs) were properly serving the students, and if the internet services were at the expected level to have adequate access to web site sources.

Finally, the researcher observed 12 thesis defense sessions which took place in Hawassa in two rounds. Of these six were from regular division and six from summer division. The observation was made with the aim of assessing the students' capacity to present and defend their research works, and to attend general comments of the examiners on the overall oral and written work and to use these comments to supplement and cross check questionnaires' and interviews' responses for evaluating students' report writing ability.

\subsection{Methods of Data Analysis}

The researcher analyzed the data gathered using the different instruments through both quantitative and qualitative methods. Data obtained using close-ended 
questionnaire items were analyzed using frequency and percentage whereas data obtained through open-ended questionnaire items, interviews and observations were analyzed using narrations and thematic descriptions.

\section{Results and Discussion}

\subsection{Instructors' Questionnaire Responses' Results}

As depicted in item 1 of Table 1, 95\% of the respondents believe that some of the students joining the program possess the basic English language skills and knowledge and almost all of them hardly possess these skills and knowledge. The instructors mentioned the following major lacks in the students:

- identifying major and supporting ideas, making notes, paraphrasing, writing summaries, and conventions of academic writing;

- study and critical thinking skills, expressing ideas clearly and logically and comprehending speeches;

- phonology, morphology, discourse, vocabulary, grammar and mechanics.

The students' responses for the same issue indicate that $43.3 \%$ of them think that they had the basic English language skills and knowledge when they joined the program and $40 \%$ of them think on the contrary (See 4.3). Results of interview responses of instructors and department heads and program coordinators, for the same issue, and defense sessions' observations, however, support the instructors' questionnaire's response result (See 5.2, $5.4 \& 5.5$ ).

Based on these responses, we can say that the students joining the program lack basic English language skills and knowledge to pursue the program effectively.

From item 2 of the table, we can see that $95.25 \%$ of the instructors believe that some of the students make adequate effort to be TEFL professionals at the required standard and almost all of them hardly make adequate effort. These instructors mentioned the following as major reasons behind the students' lack of effort:

- focusing on getting pass mark and certified rather than developing knowledge and skills in the area;

- lacking the habit and motivation to working hard and expecting easy success.

The students' responses for the same issue show that $50 \%$ of them believe that they make adequate effort (See 5.3.), on the contrary, results of interviews accord with the instructors' questionnaire responses' result (See 5.2 \& 5.4).

The same table shows that $28.56 \%$ of the instructors reported that all and most of the students can prepare appropriate term papers at the end of course work. However, $61.90 \%$ of them responded that some and almost all of the students cannot prepare term papers at the end of their coursework. These instructors listed the following major problems their MA students face in preparing term papers:

- inability to include major points and details;

- failure to integrate ideas from sources and documenting sources; 
Table 1. Instructors' responses concerning students' readiness to pursue the program, their efforts and capacity in pursuing the program.

\begin{tabular}{|c|c|c|c|c|c|c|}
\hline \multirow[t]{2}{*}{ No. } & \multirow[t]{2}{*}{ Issue } & \multicolumn{5}{|c|}{ Responses } \\
\hline & & & Ath & Mth & Sth & An \\
\hline \multirow[t]{2}{*}{1} & $\begin{array}{l}\text { Do you think MA TEFL students join the } \\
\text { program with the basic English language skills }\end{array}$ & Fr. & 0 & 1 & 15 & 5 \\
\hline & $\begin{array}{l}\text { and knowledge to pursue the program so as to be } \\
\text { highly qualified professionals in the area? }\end{array}$ & $\%$ & 0 & 4.76 & 71.42 & 23.8 \\
\hline \multirow[t]{2}{*}{2} & Do your MA students make adequate effort to & Fr. & 0 & 1 & 17 & 3 \\
\hline & become highly qualified professionals in the area? & $\%$ & 0 & 4.76 & 80.95 & 14.3 \\
\hline \multirow[t]{2}{*}{3} & Do your MA TEFL students prepare and present & Fr. & 1 & 5 & 11 & 4 \\
\hline & $\begin{array}{l}\text { term papers at the end of their course at the } \\
\text { standard they are expected to do so? }\end{array}$ & $\%$ & 4.76 & 23.8 & 52.38 & 19.04 \\
\hline \multirow[t]{2}{*}{4} & If you have ever been MA TEFL thesis & Fr. & 0 & 4 & 14 & 3 \\
\hline & $\begin{array}{l}\text { advisor/co-advisor, could your advisees prepare } \\
\text { sound research proposals at the end? }\end{array}$ & $\%$ & 0 & 19.04 & 66.66 & 14.28 \\
\hline \multirow[t]{2}{*}{5} & $\begin{array}{l}\text { If you have ever advised MA TEFL students in } \\
\text { their thesis work, could they write a good research }\end{array}$ & Fr. & 0 & 3 & 16 & 2 \\
\hline & report at the end? & $\%$ & 0 & 14.28 & 77.19 & 9.52 \\
\hline \multirow[t]{2}{*}{6} & $\begin{array}{l}\text { If you have ever been an examiner for MA TEFL } \\
\text { research proposal or thesis work defense, could }\end{array}$ & Fr. & 0 & 4 & 13 & 4 \\
\hline & $\begin{array}{l}\text { your examinees defend their research work } \\
\text { confidently and effectively? }\end{array}$ & $\%$ & 0 & 19.04 & 61.90 & 19.04 \\
\hline
\end{tabular}

Key: Ath $=$ All of them, Mth $=$ Most of them, Sth $=$ Some of them, An = Almost no, Fr. $=$ Frequency

- inability to construct appropriate sentences and paragraphs;

- poor in organization, grammar and mechanics.

Instructors' interview result of related issue accord with the above result (See 5.2).

Item 4 of Table 1 indicates that $4(19.04 \%)$ of the instructors responded that most of the students can at the end prepare sound research proposals. On the other hand, 17 (80.94\%) of them; answered that some of the students can prepare sound research proposals and all of them can hardly do that at the end. These respondents noted the following major problems the students have in writing research proposals:

- lack of proposal organization knowledge and skills;

- failure to review adequate and relevant literature;

- failure to identify components of a research proposal and to incorporate essential contents;

- lack of clear understanding on methodological aspects of a research proposal;

- duplicating other researchers' work rather than developing their own;

- failure to exploit feedback.

Instructors' interview responses concur with the above responses of the instructors (See 5.2).

As it can be seen in item 5 of Table 1, 14.28\% of the instructors responded that most of the students can write a good research report. Yet $86.71 \%$ of them 
reported that some of the students can write good research reports and all can hardly write good reports. In addition to the ones listed above, the instructors listed the following as the MA students' major problems in writing research report:

- lack of critical evaluation and analysis;

- failure to organize and analysis data;

- mismatch between objectives and the findings;

- lack of description of the procedures taken and their justification;

- failure to state the problem they want to investigate and linking the problem with what has been done before;

- lack of clear and strong argument;

- using inappropriate and inadequate data gathering tools;

- failure to apply research report writing conventions.

The instructors' interview result for similar item goes with the above result (See 5.2).

In item 6 of Table 1, we can observe that only 4 (19.04\%) of the instructors responded that most of the examinees can defend their proposals and research reports confidently and effectively. But $80.90 \%$ of them responded that some of them and few of their examinees can defend their proposals and research reports confidently and effectively. These instructors listed the following as the major problems the students face while presenting and defending their proposals and theses:

- deficiency of appropriate language and fluency;

- failure to focus and select areas for presentation;

- lack of confidence to present their work and to answer questions.

The thesis defense sessions' observation allowed the researcher to confirm that the majority of the presenters have the above and some more deficiencies (See 5.5).

As depicted in item 1 of Table 2, 61.9\% of the instructors rated their advisees' overall performance on their thesis work as good, $19.04 \%$ of them as satisfactory and $19.04 \%$ of them as poor. The department heads' and the program coordinators'

Table 2. Instructors' responses regarding prospective graduates' performance on their thesis work and the graduates' professional quality.

\begin{tabular}{lccc}
\hline \multicolumn{1}{c}{ Issue } & Responses & Fr. & $\%$ \\
\hline $\begin{array}{l}\text { No. you have ever advised MA TEFL students in their } \\
\text { thesis work, how do you rate the overall performance } \\
\text { of your advisees on their thesis work? }\end{array}$ & Excellent & 0 & 0 \\
1 Very good & Good & 13 & 61.9 \\
& Satisfactory & 4 & 19.04 \\
& Poor & 4 & 19.04 \\
$\begin{array}{l}\text { Do you think that your department is graduating } \\
\text { highly qualified professionals in Teaching English as a } \\
\text { Foreign Language (TEFL)? }\end{array}$ & Yes & 3 & 15 \\
& No & 13 & 65 \\
\hline
\end{tabular}


interview responses for the same issue and the examiners' general comments, however, indicate that most of candidates do not deserve to get more than satisfactory grade.

From item 2 of Table 2, we can understand that $15 \%$ of the instructors answered that they think that their departments are graduating highly qualified professionals. However, $65 \%$ of them answered on the contrary and $20 \%$ of these instructors could not be certain. The instructors who do not think that their departments are graduating highly qualified TEFL professionals suggested the following to be done to bring about the required professional standard:

- the curricula and admission requirements should be revised and selection of students should be done carefully;

- adequate attention should be given to quality of lessons delivery, assessment, follow-up, input provision and building capacity of teachers in all levels of education;

- the program should be checked based on the road map designed for KG to undergraduate levels.

Results of instructors, department heads and program coordinators' interviews for the same issue justify that the English Language and Literature Departments are not producing adequate TEFL graduates at the expected standard (See $5.2 \& 5.4$ ).

\subsection{Instructors' Interview Results}

The first interview item was concerned with the students' readiness to pursue the program effectively. The instructors told the researcher that only few students join the program with the required knowledge and skills to pursue the program successfully. They added that most of them join the program without basic research knowledge and skills and critical thinking capacity. As the instructors said, the root cause of this problem is many folds and it makes vicious circle. The problem mainly emanates from the English language education system they passed through. The instructors stated that lack of quality English language teachers starting from elementary level to higher institutions, lack of appropriate assessment strategies and motivation to learn the language are the major causes of the deficiency. The instructors also emphasized that lack of quality English language education at undergraduate level negatively contributes to poor background in the language at MA level.

Next, the interviewees were asked if the students make sufficient effort to develop their knowledge and skills in the field. Most of the instructor stated that the majority of the students do not make sufficient effort to develop their skills and knowledge in the area. They said the majority of the students are not motivated to do that; they are pursuing the program jut to be certified and to get the financial benefit as a result of the certification. The instructor mentioned some factors for the students' fail to make adequate effort. The first one is related to motivation. The major focus of sponsors and recruiting institutions is on certi- 
fication and not on students' qualification. The students know this very well and do not want to make their level best effort. The second one is related to their previous learning experience and the capacity gap incurred owning to poor quality English language education. The instructors told the researcher that the majority of the students lack the habit of reading further, critically and reflecting on what they have read logically.

In connection with the above issue, most of instructors informed the researcher that the majority of the students do not properly exploit the feedback given on their term papers, proposals and research reports and submit back their work without incorporating essential comments. The instructors mentioned students' recklessness to improve their work and their skills and knowledge as the root cause.

The next two items of the interview were concerned with the students' potential to develop sound research proposals and research reports at the end of the program. Most of the instructors stated that this is the challenging area for most of the graduates. Most of them said that most of the graduates lack the basic skills and knowledge of conducting research. They do not know how research work flows from the very beginning to the end. They explained that research work is a very demanding task but most of the graduates do not seem to possess the skills and knowledge to accomplish this task. The instructors mentioned several causes for the problems. The first one is lack of researching culture and experience at undergraduate level and their work places. Shallow emphasis is afforded to the practical aspect of research at undergraduate level. This limits students getting adequate practice and experience and has extended impact on postgraduate level. The students also misuse and steal research works carrying out by others, the whole or portions of them, usually with some modifications. This bad practice prevents them from practicing conducting their own research. The instructors also reported that the majority of the students fail to identify the components of a research proposal and a research report and what sort of issues to be discussed under each component. The instructors also added that the students have problems in selecting relevant topics and sub-topics for literature review.

The instructors forwarded the following suggestions to curb this huge problem. First, due emphasis should be afforded to both the research course and senior essay research work at undergraduate level. Second, researching culture or practice should be developed at schools where most of the postgraduate students come from and some sort of training should be given to the graduate students prior joining the program. Thirdly, universities and other research centers must establish networking system to control theft in research works collaboratively.

Next, the instructors were asked whether the courses that MA TEFL students take are adequate or not. The majority instructors from Hawassa and Dilla Universities felt that some courses should be added and the contents of the exiting courses should be revised. They suggested offering the general Research Metho- 
dology course in quantitative and qualitative method courses separately but some said offering the course in an intensive and practical oriented manner would be better. However, most of these instructors feel that the curriculum should be revised and some amendment should be made. One of these instructors from Hawassa University informed the researcher that the curriculum was revised two years ago and some amendment on courses was made and approved at department level but for unknown reason, the vice president office did not respond. Likewise, one instructor from Dilla University revealed that the curriculum was revised a year ago and some amendments were made. The department head and the program coordinators' responses for the same issue substantiated what the instructor said (See 5.4). In the case of Wolayta Sodo University, the department head the program coordinator felt that the courses are adequate but they did not have any justification for that.

Finally the researcher asked the instructors if they think the English Language and Literature Departments are graduating adequate well qualified MA TEFL professionals. Most of them responded that the departments are graduating the majority of the MA students they admit but their professional quality is questionable. They relate the decline in the professional quality with the decline in quality in English language education. This heavily hampers the Departments in their effort to produce highly qualified professionals. The instructors also related the degrading in the professional quality with the great emphasis given to certifying MA holders rather than qualifying them. Mass certification required to fill the demand for English language teachers. The instructors explained that the ministry of education interferers in the selection of the MA TEFL students, in particularly in the selection of summer division students. It selects the students without involving the departments, so it deprives of their autonomy. The departments themselves cannot secure their autonomy because they lack courage to reject order and they desire to have the program with adequate number of students. Furthermore, the instructors attributed the decline to the recklessness of the majority of the students and some instructors.

As per the researcher's request for recommendations for assuring educational quality in the program, most of the instructors started forwarding their suggestions by stating the decisiveness of cooperative effort of all stakeholders to bring about educational quality as the problem makes a vicious circle and can only be resolved through working cooperatively and collaboratively. Then, first they said the ministry of education should strengthen the reform process on the sector it has started. It should be serious and firm in controlling English language education quality. There should not be any compromise on the expense of quality of education. All efforts should gear towards bringing about quality of education rather than quantity, qualification rather than certification. Second, educational institutions must make their best level effort to guarantee quality of English language education.

In line with the above points, instructors underscored the need for designing 
appropriate curricula, admitting only legible students, recruit quality instructors, fulfill necessary facilities and materials and make adequate follow up for the implementation of the curriculum at university level. The instructors added that English Language Departments at low level are expected to act in a similar manner to assure quality of English language education. The instructor also suggested that there should be continuous professional capacity building trainings for English language teachers.

\subsection{Students' Questionnaire Responses' Results}

In item 1 of Table 3, it can be seen that $43.3 \%$ of the respondents think that they had the basic background English language skills and knowledge when they joined the program but $40 \%$ of them believe that they had no. Similar data analysis results show that most of the students joined the program without basic knowledge and skills (See 5.1, 5.2 \& 5.4).

From item 2 of Table 3, we can see that $50 \%$ of the students believe that they make adequate effort to become highly qualified professionals in TEFL, whereas $50 \%$ of them think on the contrary. Other data analysis results show that most of

Table 3. Students' responses on their readiness to pursue the program, adequacy of their efforts, support they get, courses offered and service provision.

\begin{tabular}{|c|c|c|c|c|c|}
\hline \multirow{2}{*}{ No. } & \multirow{2}{*}{ Issue } & & \multicolumn{3}{|c|}{ Responses } \\
\hline & & & Yes & No & Uncertain \\
\hline \multirow[b]{2}{*}{1} & \multirow{2}{*}{$\begin{array}{l}\text { Do you think that you had the basic English language } \\
\text { skills and knowledge when you joined the MA program? }\end{array}$} & Fr. & 13 & 12 & 5 \\
\hline & & $\%$ & 43.3 & 40 & 16.7 \\
\hline \multirow[b]{2}{*}{2} & \multirow{2}{*}{$\begin{array}{l}\text { Have you adequately endeavored to develop your skills } \\
\text { and knowledge in your field of study? }\end{array}$} & Fr. & 15 & 15 & \\
\hline & & $\%$ & 50 & 50 & \\
\hline \multirow[b]{2}{*}{3} & \multirow{2}{*}{$\begin{array}{l}\text { Have you } \\
\text { library? }\end{array}$} & Fr. & 27 & 3 & \\
\hline & & $\%$ & 90 & 10 & \\
\hline \multirow{2}{*}{4} & \multirow{2}{*}{$\begin{array}{l}\text { If your response for item } 3 \text { is "Yes", have you got adequate } \\
\text { and up-to-date reference materials in the library? }\end{array}$} & Fr. & 7 & 20 & \\
\hline & & $\%$ & 25.9 & 74.1 & \\
\hline \multirow{2}{*}{5} & \multirow{2}{*}{$\begin{array}{l}\text { Have you wanted to get Internet services from the } \\
\text { university? }\end{array}$} & Fr. & 28 & 2 & \\
\hline & & $\%$ & 93.3 & 6.7 & \\
\hline \multirow[b]{2}{*}{6} & \multirow{2}{*}{$\begin{array}{l}\text { If your response for item } 5 \text { is "Yes", have you got } \\
\text { adequate Internet access in the university? }\end{array}$} & Fr. & 18 & 12 & \\
\hline & & $\%$ & 60 & 40 & \\
\hline \multirow[b]{2}{*}{7} & \multirow{2}{*}{$\begin{array}{l}\text { Have you got the necessary support from your thesis } \\
\text { advisors? }\end{array}$} & Fr. & 22 & 7 & 1 \\
\hline & & $\%$ & 73.3 & 23.3 & 3.3 \\
\hline \multirow[b]{2}{*}{8} & Have you got enough support from the concerned & Fr. & 19 & 5 & 6 \\
\hline & $\begin{array}{l}\text { administrative bodies in your effort to become } \\
\text { professional at the required standard in the area? }\end{array}$ & $\%$ & 63.3 & 16.7 & 20 \\
\hline \multirow[b]{2}{*}{9} & Do you think that the courses for the MA TEFL & Fr. & 18 & 9 & 3 \\
\hline & $\begin{array}{l}\text { program are sufficient to develop your theoretical } \\
\text { knowledge and practical skills in the field? }\end{array}$ & $\%$ & 60 & 30 & 10 \\
\hline
\end{tabular}


the students do not make sufficient effort (See 5.1, $5.2 \& 5.4$ ).

Items 3 and 4 of the table indicate that $90 \%$ of the students want to get services from their universities libraries and $74.10 \%$ of these respondents answered that they do not get adequate and up-to-date services. Results of resource centers observation and the department heads' and the program coordinators' interview show that there are some problems in that regard (See $5.4 \& 5.6$ ).

From the same table items 5 and 6 we can see that $93.3 \%$ of the students want to get internet services in their universities and $62.3 \%$ of these answered that they get adequate internet services. Similarly resource centers observation and the department heads' and the program coordinators' interview results indicate that there are somewhat sufficient Internet services in the universities (See 5.4 \& 5.6).

From the same table, item 7, it can be seen that most of the students indicated that they get the necessary support from their thesis advisors. The department head' and the program coordinators' interview results also back up this (See 5.4). All the results, however, indicate that there are some instructors who do not render adequate support to their advisees.

Item 8 of Table 3 indicates that the majority of the respondents answered that they get sufficient support from concerned administrative bodies. The department heads' and the program coordinators' interview results also substantiate this (See 5.4).

Item 9 of the table depicts that more than half of the students think that the courses they take are sufficient to help them develop their theoretical knowledge and practical skills. The results in 5.2 and 5.4, however, imply that the courses have not been adequate to develop the students' knowledge and skills in the area.

From Table 4 it can be seen that the majority of the students indicated that they get the necessary support from their course instructors. The department heads and the program coordinators' interview results also back up this (See 5.4). Instructors' interview results, however, indicate that there are some instructors who do not render their support to the students.

Table 4. Students' responses concerning course instructors' support to them.

\begin{tabular}{ccccc}
\hline No. & \multicolumn{1}{c}{ Item } & Responses & Frequency & Percent \\
\hline 1 & $\begin{array}{l}\text { Have your course instructors rendered you } \\
\text { with the necessary support? }\end{array}$ & All of them & 12 & 40 \\
& Most of them & 9 & 30 \\
& Some of them & 9 & 30 \\
& Almost no & 0 & 0 \\
\hline
\end{tabular}

\subsection{English Language and Literature Department Heads and TEFL Postgraduate Coordinators' Interview Results}

The first question raised to the heads and coordinators was regarding students' admission requirements to the program. First they informed me that the program has three divisions: regular, summer and weekend. The interviewees said 
that they are somewhat autonomous to select candidates for the regular and weekend divisions and use some criteria. As a prerequisite, applicants should have BA or BED degree in English language or other local languages. Hawassa and Dilla Universities use other similar criteria. They give entrance exams that accounts for $50 \%$ and for the rest 50\% they consider experience, CGPA and gender. Wolayta Sodo University, however, uses only entrance exam to select students for the regular and weekend divisions.

In selecting summer students, the interviewees said the departments are hardly involved. The Ministry of Education gives exam and send students' list. The universities and the departments may be involved as centers and in assigning invigilators. Some interviewees revealed students who score very poor marks in the entrance exam will sometimes be selected.

The interviewees were also asked if they have ever refused to accept illegible students sent by the ministry of education. Only one of them said that his department rejected a candidate who had BA degree in unrelated field. The other told the researcher that their departments are not in a position to do that. As the respondents replied, this is because they have to provide services as per orders. As some instructors disclosed and as the researcher himself observed, there are two basic reasons for the departments' failure to secure their autonomy. The first one is fear of attack from their superiors. Second, the department heads, the program coordinators and some instructors want to have a lot of students for the sake of getting experience and financial benefit.

The interviewees were questioned if candidates join the program with basic knowledge and skills. Most of them explained most of the students have deficiency in basic knowledge and skills to pursue the program effectively. They attributed the lack of ability to the prevalence of degrading quality of English language education. The interviewees mainly blamed the undergraduate English Language and Literature Program for not laying the basis for the MA program.

The third question was whether the students make adequate effort to become highly qualified professionals in the field. The majority of the interviewees stated that the majority of the students do not make sufficient effort. They mentioned several interrelated causes. The first one is lack of hard working habit to be knowledgeable and skillful. The students develop the tendency to be successful without making sufficient effort. In the case of MA TEFL students, the interviewees said that they are very much dependent on other sources. Lack of motivation is another cause they mentioned which is a consequence of lack of visible change in their life even if they make their outmost effort. The interviewees informed the researcher that the students' recklessness results in burden on the instructors. They have to render extra support in order to enable the students to have at least the minimum capacity for that level.

With regard to the effort of the students on their thesis work, the interviewees added that conducting research is the most challenging area for the students as it requires great effort to succeed. The students, nevertheless, do not exert that ef- 
fort, rather they copy and paste what they get and mix them even without integrating them. They added the majority of the students conduct MA thesis to get certificate and they may not conduct research afterwards because of their poor skills and lack of effort for self-improvement. The interviewees suggested admitting students who are able to pursue the program effectively.

In responding to the item regarding the availability of sufficient instructors for running the program, the interviewees from Hawassa University assured the researcher that the department has enough instructors for the program. The researcher also learned that the department has 18 instructors who have the required qualification for the level. Interviewees from Dilla and Wolayta Sodo Universities informed the researcher that they do not have adequate instructors. They have 5 and 4 instructors respectively. The heads and coordinators revealed that instructors will have 7 to 9 thesis advisees at once. This largely affects the advisees' thesis work and sometimes they are forced to delay their years of study. They are waiting the $\mathrm{PhD}$ candidates who are studying in different universities rather than hiring or outsourcing other legible instructors. The interviewees stated that to curb advisors' shortage they use these candidates. To solve course related problems they get support from instructors who specialized in related fields.

Most of the heads and coordinators admitted that most of the instructors render sufficient support to the students. Some of the interviewed instructors, conversely, revealed that there are some instructors who fail to render the required support to their students and advisees. They added the departments may not be informed as they often refrain from intervening in such affairs.

The interviewees were also questioned if the courses offered in the program are adequate or not. The interviewees from Hawassa and Dilla Universities explained that the departments recognized the need for revising the curricula, revised them and made some amendments. They reported that a course on Academic Reading and Writing has been added. In the case of Dilla University additional Applied Linguistics to Teaching English has been added. Besides, some topics have been embedded into some existing courses. The researcher informed the heads and the coordinators that some instructors suggested offering the general course Research Methodology as two courses: Quantitative and Qualitative and extending the 2 years to 3 . Regarding the course they said it would be better to deal with the course intensively affording due emphasis to its practical aspects rather than treating them separately. Concerning the year of the program, they said 2 years is enough if the students and the instructors work efficiently and in collaboration. The heads and coordinators from Hawassa University told that the revised curriculum was sent to the vice president office for approval. In the case of Dilla University the new curriculum has already been put into practice. The interviewees from Wolayta Sodo University told me that they did not revise the curriculum but they thought that the courses are adequate.

The heads and coordinators were moreover asked if the students get adequate 
services from resource centers and support from administrative bodies. Regarding library service, interviewees from Dilla University told that the university has a postgraduate library and the students can get service there. These interviewees, however, revealed that the library has no ample rooms to accommodate all service seekers. They also disclosed that there are no sufficient updated books. The heads and coordinators from Hawassa and Wolayta Sodo Universities reported that there are no libraries that are purposely organized and facilitated for postgraduate programs and said the students are not getting adequate library services. Concerning Internet services, most of the interviewees said that the candidates can get the services from social science libraries, main libraries, around offices and in cafeterias, albeit the quality of the service is not at the required standard. With regard to support from concerned administrative bodies, the interviewees assured that every concerned administrative body is willing to render any necessary support. The researcher's resource centers observation helped him to confirm that what the interviewees said regarding services is factual (See 5.6).

The researcher then asked interviewees to rate the candidates' course work and thesis work performance. Most of the interviewees rate most of the graduates' course work performance as good. In their research work, the majority of the interviewees rated the majority graduates' thesis work as satisfactory.

Finally, I asked the heads and coordinators if they think that their departments are graduating adequate MA TEFL professionals at the expected standard. The majority of them answered that their departments are graduating the majority of the students they admit but they doubt that the graduates are at the excepted professional standard. They said instructors and the departments exert their maximum efforts to help the students fulfill the minimum graduation requirement and the majority of them are certified, but their professional quality is questionable. They mentioned several contributing factors for the decline in quality. They listed deterioration of the quality of English language education, admitting unready students, lack of motivation and responsibility in the majority of the students and some instructors, misuse and over dependency on web site resources and other non-online resources, lack of continuous and adequate professional capacity building opportunities particularly in high schools as contributing factors for the decline.

The researcher furthermore requested the interviewees to forward their suggestions to bring about the professional quality in the program. They advanced a number of suggestions. First they stated that the quality of English language education needs improvement starting from the very beginning. To this end, all stakeholders should play their own roles. To bring about quality in English language education, first quality English language teachers ought to be produced, English language professional capacity building opportunities should be created, the quality of teaching-learning and assessment process should be given due attention and the necessary facilities and materials should be fulfilled. Second, the interviewees said only students who possess the basic skills and knowledge to 
pursue the program successfully should be admitted. Third, adequate emphasis should be afforded to professional quality of the MA TEFL graduates rather than trying to fill English language teachers demand through certifying MA holders.

\subsection{Thesis Defense Sessions' Observation Result}

From the researchers personal observation of thesis defense sessions and the examiners' comments he learned that most of the prospective graduates have the following comment defects:

- failure to present major ideas succinctly, fluently and logically;

- failure to answer questions and to manage time;

- lack of standard language, clarity, brevity and focus in the report;

- vagueness and inadequacy in sampling;

- employing inappropriate and inadequacy data gathering tools;

- including unconcerned respondents and irrelevant items in the questionnaires and interviews;

- erroneous organization, presentation, analysis and interpretation of data;

- mismatch and inconsistency among major parts of the papers;

- drawing conclusions and forwarding recommendations out of the findings;

- failure to select relevant review of literature, to quote, paraphrase and summarize ideas from sources and to document sources.

\subsection{Resource Centers' Observation Result}

The researcher's observation and information he obtained from responsible bodies informally in Hawassa University, signifies that the MA TEFL students are not getting efficient quality library services owing to absence of separate libraries for them. Moreover, the reference materials found in the social science library were not properly arranged and most of them were outdated. From the main library, the students could get model thesis papers and general reference materials. The ELIC is not serving for no permanent person was assigned to run it. Though there is no a separate and well organized internet service center in the university, the students could get internet services here and there.

In Dilla University there is one graduate library which serves all postgraduates in a room that can accommodate about 25 customers at once. There are some desk top computers, some references and some MA TEFL theses. Because of internet service problem, students were not getting e-books and other web related services. In Social Sciences library there were some journals and hard copies. The ELIC is hardly providing services as there is no responsible body to run the center effectively.

In Wolayta Sodo University there is one graduate library but it is not properly functioning as the necessary facilities and materials are not available and accessible. E-Books, hard copies, most of them outdated, MA TEFL and PhD research papers, soft copies of references reserved by teachers and internet service were available in the main library. In the Social Sciences Library there was internet ser- 
vice but very slow. The ELIC center was not at all serving postgraduate students.

\subsection{Discussion}

Students joining the program are required to possess the basic knowledge and skills to pursue the program successfully and to become highly qualified professionals in the field. The findings of the analysis of both quantitative and qualitative data, however, show that most of the students lack these basic knowledge and skills. The deficiency is attributed to the decline in English language education in general and at undergraduate level in particular and lack of continuous and relevant professional capacity building opportunities. Over and above, most of the students do not make adequate effort to develop their knowledge and skills and to become well qualified professionals. Lack of motivation and hardworking experience are the major causes for this. Deficiency in the basic knowledge and skills and effort along with other challenges largely affects the production of highly qualified professionals in the area.

The findings indicate that most of the students could not prepare appropriate term papers for the courses they took. They submit term papers which have organization, content and language problems. Besides, they could not properly incorporate ideas from other sources. The students have a big problem in developing proposals, conducting research and writing up research reports. They do not know how a research work goes from the very beginning up to the end and the conventions of developing proposals, conducting research and writing up research reports. They do not identify the components of research proposal and research report and what each component should deal with. Most of the students also draw conclusions and forward recommendations out of the findings of their thesis works. They also fail to use standard language and follow scientific principles in developing proposals, conducting research and writing up research reports.

Most of the students have great problems in selecting and developing data collecting tools, sampling respondents, organizing, analyzing data and interpreting them. They also have huge problem is selecting relevant review of literature, quoting, paraphrasing and summarizing ideas from other sources and documenting sources of information. They also abuse sources and mix up unrelated ideas via coping and pasting from different sources. Most of the students also fail to present and defend their thesis works clearly, succinctly, fluently and logically.

Although the majority of the students want to get library services from the universities, the service provision is inadequate. The majority of the students also want to get internet services and comparatively they get a better service. The students also require instructors and administrative bodies' support. Except some instructors who fail to shoulder their responsibilities, the instructors and administrative bodies do their best to help the students.

In the three universities, students who are illegible to join the program are 
admitted, particularly in the summer division. This becomes a big challenge in the production of well qualified professionals in the area. Due emphasis is afforded to certifying MA TEFL holders but not to qualifying them. This is done to satisfy the demand of English language teachers in high schools, colleges and universities. This will aggravate the decline in the quality of English language education.

The departments of Hawassa and Dilla universities have attempted to revise their curricula and made some amendments on the courses they offer. They add courses and embedded some issues into the existing courses. But the department in Wolayta Sodo University has not attempted to do the revision and even the concerned bodies do not have the idea to do so. The departments in Dilla and Wolayta Sodo Universities have shortage of instructors. This largely affects the properly offering of courses and supporting and running the thesis work. The departments are forced to offer some courses using instructors who are not legible to deliver the courses. They are also obliged to use PhD TEFL candidates studying in different universities to advise students in their thesis work. As a result of these, some students are forced to delay their thesis work and prolong their study years.

\subsection{Conclusions}

This research was conducted to evaluate the practices of running the MA TEFL Program in SNNRS government public universities. To that end, three universities in the regional state were selected. 21 TEFL instructors, 30 MA TEFL prospective graduates, 4 English Language and Literature Department heads and 4 TEFL postgraduate program coordinators were respondents in the study. Questionnaires, semi-structured interviews, resource center and thesis dense sessions observations were used for gathering relevant data. The data gathered were organized systematically and analyzed using both quantitative and qualitative methods. On the basis of the results of the analysis the following conclusions are drawn:

1) The majority of the students join the program without the basic knowledge and skills to pursue the program effectively and final to become highly qualified professionals. There are several contributing factors for the deficiency. The decline of the quality of English language education at all levels in general and at undergraduate level in particular and lack of continuous and rigorous professional capacity building and researching practices are the major contributing factors.

2) The majority of the students do not make adequate effort to develop their knowledge and skills in their field of study. Lack of motivation and hardworking experience are the main causes of effort inadequacy.

3) The majority of the students cannot prepare appropriate term papers. They cannot use standard language, include relevant contents and organize these contents clearly and logically. 
4) Most of the students are trapped with severe problems to develop research proposals, to conduct research and to write up research report. In this regard, they have the following specific problems:

- lack of knowledge and experience in conducting research and writing up research reports conventionally,

- failure to identify major components and elements and relationships among them and what each major component and element should focus on,

- failure to maintain the scope of the research,

- setting overlapping objectives,

- using inadequate and inappropriate research tools and constructing irrelevant and ambiguous items,

- failure to paraphrase, summarize, quote texts from other resources and to document sources of information and

- using non-standard and poor language.

5) The majority of the students are largely dependent on others' work. They simply copy and paste from online and non-online resources and mix them up texts in a confusing manner.

6) Most of the students are poor in oral fluency, word choice, focus and time management during presentation.

7) There are a few instructors who do not render their support to their students and advisees.

8) Though the degree varies, there is lack of library and internet services in the universities.

9) The departments in Hawassa and Dilla Universities have revised their curricula and made some amendments by adding some courses and some contents into the existing courses. The department in Wolayta Sodo University, however, has not revised the curriculum and even the concerned bodies have not had the thought of doing that.

10) Due emphasis has been given only to certifying as many of the students joining the program as possible in order to fill the demand gap in high schools, colleges and universities and other related areas rather than producing well qualified MA-TEFL professionals.

11) The admission of students to the program, particularly summer division students, has not been done carefully. As a result students who are illegible to join the program and who cannot pursue the program successfully are admitted.

12) Owing to the number of problems listed above, it is possible to say that the English Language and Literature Departments in the three universities are graduating well qualified MA-TEFL professionals.

\subsection{Recommendations}

Based on the conclusions drawn above the following recommendations are forwarded:

1) To improve the declining in quality of English language education, the Min- 
istry of Education should strengthen the reform effort in the sector and take it up to post graduate level.

2) English language education at undergraduate level should be afforded due attention.

3) Quality of English language education at post graduate level should be given sufficient attention rather than quantity of certifying students to fill the demand gap because this aggravates the quality problem rather than bringing about quality education. To this end,

- only students who are legible to join the program should be admitted,

- the necessary facilities and materials should be made available and accessible,

- to control plagiarism, the universities in the country should create connections among their web pages and set mechanisms to control plagiarism from world wide web site resources and take corrective measure on those who commit plagiarism,

- necessary follow up should be made on instructors who fail to render their support to their students and advisees,

- graduates who worked hard and earned high results should be encouraged so that others would work hard,

- adequate courses should be given with adequate emphasis for both theory and practice.

4) Professional and researching capacity building opportunities should be created for ELT graduates, in particular for first degree graduates.

5) All stakeholders, especially students, instructors, department heads, program coordinators and other administrative bodies should actively involve themselves in order to improve English language education which contributes to the improvement at postgraduate level.

6) The English Language and Literature Departments must revise the MA-TEFL program curricula timely and make improvements if need be.

7) Similar research should be carried out in the other universities in order to strengthen the findings of this research.

\section{Conflicts of Interest}

The author declares no conflicts of interest regarding the publication of this paper.

\section{References}

Abbasian, G., \& Teheri, N. (2016). Evaluation of Iranian TEFL M.A. Program in Terms of Compatibility with Common Standards: Teachers' Perspective. ELT Voice International Journal of Teachers of English, 6, 31-51.

Aliakbari, M., \& Ghoreyshi, M. (2013). On the Evaluation of Masters of Arts Program in Teaching English as a Foreign Language. Iran: Ilam University.

Anto, G., Conders, F., \& Voodt, J. (2012). Assessing the Current Implementation of Communicative Language Teaching for English Language Teachers in Ethiopian Universities. Staff and Educational Development International, 16, 51-69. 
Brawn, J. D. (1995). The Elements of Language Curriculum. Boston: Heinele an Heinel.

Brinkerhoff, R. O. (1983). Program Evaluation: A Practitioner's Guide for Trainers and Educators (3rd ed., 1986). Kalamazoo, MI: Western Michigan University.

Dilla University, Hawassa University, \& Wolayta Sodo University (2011-2013). Curricula in Masters of Arts in Teaching English as a Foreign Language (TEFL).

Dollar, K. Y., Tolu, A. T., \& Doyran, F. (2014). Evaluating a Graduate Program of English Language Teacher Education. Turkish Online Journal of Quality Education, 5, 1-10.

Eshetie, A. B. (2010). Language Policies and the Role of English in Ethiopia. A Paper Presented at the 23rd Annual Conference of IATEFL/BESIG.

Frye, A. W., \& Hemmer, P. A. (2012). Program Evaluation Models and Related Theories: AMEE Guide No. 67. Medical Teacher, 34, e288-e299.

https://doi.org/10.3109/0142159X.2012.668637

Institute of International Education (2012). Enhancing the Quality of English Language Education in Ethiopia. Report on a Future Research Conference. IIE Briefing Paper. https://www.iie.org/

Jarvis, A. G., \& Adams, J. S. (1979). Language in Education: Evaluating Second Language Program. Washington DC: Virginia Center for Applied Linguistics.

Kader, B. (2016). Curriculum Evaluation of Professional Postgraduate ELT/TESOL Program: A Study in Bangladeshi Institute. Bangladesh: Barac University.

Keating, S. B. (2011). Curriculum Development and Evaluation in Nursing. New York: Spring Publishing Company.

McNamara, C. (2000). The Field Guide for Nonprofit Program Design. Marketing and Evaluation. Minneapolis: Authentic Consulting.

Mede, E. M., \& Uygun, S. (2014). Evaluation of a Language Program. International Association of Research in Foreign Language Education and Applied Linguistics. ELT Research Journal, 3, 201-221.

Oerman, M. H., \& Gaberson, K. (2009). Evaluating and Testing in Nursing Education. New York: Spring Publishing Company.

Sanders, J. R., \& Sullins, C. D. (2006). Evaluating School Programs. Thousands Oaks, CA: Corwin Press.

Soontornwipost, K. (2008). An Impact Evaluation of a Masters in TEFL Program. Thailand: Melbourne, Victoria University. A Dissertation for Doctor of Education.

Stavropoulou, A., \& Stroubouki, T. (2014). Evaluating Educational Programs: The Contribution of History to Modern Evaluating Thinking. Health Science Journal, 8, 193-204.

Stufflebeam, D. L. (2003). The CIPP Model for Evaluation. Portland, Oregon: Annual Conference on the Oregon Program Evaluators Network (OPEN).

Tyler, R., Robert, M., \& Michel, S. (1967). Perspective of Curriculum Evaluation. Chicago: Rand McNall.

Wang, X. (2009). Assessing and Evaluating Adult Learning in Career and Technical Education. Hangzhou: Zhejiang University. 